\title{
Clinical outcomes of COVID-19 amongst HIV patients: a systematic literature review
}

\author{
Thomas Massarvva \\ Department of Primary Care and Population Health, University of Nicosia Medical School, Nicosia, Cyprus
}

\begin{abstract}
OBJECTIVES: The global pandemic coronavirus disease 2019 (COVID-19) emerged in the city of Wuhan, China around December 2019. Since then, the virus has caused severe morbidity and mortality worldwide and has put pressure on the global medical system. Still, there are limited data regarding the clinical impact of COVID-19 on people living with human immunodeficiency virus (HIV). The primary aim of this study was, therefore, to systematically review up-to-date studies reporting the clinical outcomes of COVID-19 amongst HIV patients.

METHODS: A thorough literature search was carried out using MEDLINE, Embase, Scopus, and the Cochrane Library Databases in accordance with the PRISMA (Preferred Reporting Items for Systematic Reviews and Meta-Analyses) guidelines.

RESULTS: A total of 22 studies were identified. Amongst 730 HIV/COVID-19-coinfected patients, $79.4 \%$ were males, the median age was 51.5 years, and the number of reported patients receiving antiretroviral drugs was 708 (97.2\%). Most coinfected patients had mild to moderate symptoms, including cough (37.7\%), fever (37.5\%), and dyspnoea (24.7\%). Among pre-existing comorbidities, hypertension (26.3\%) was the most prevalent in HIV/COVID-19 coinfected patients, and 87\% of coinfected patients recovered.

CONCLUSIONS: Based on the existing data in this systematic literature review, HIV patients with pre-existing comorbidities, obesity, and older age should be considered as a high-risk group for COVID-19. Furthermore, coinfected patients appear to have marginally comparable clinical outcomes with the general population. The study's findings highlight the need for further investigation to elucidate the impact of COVID-19 infection on HIV patients.
\end{abstract}

KEY WORDS: COVID-19, SARS-CoV-2, Infections, HIV, Coinfection, Acquired immunodeficiency syndrome

\section{INTRODUCTION}

A new pandemic, severe acute respiratory syndrome coronavirus 2 (SARS-CoV-2), was initially reported in Wuhan, China, on December 31, 2019 [1]. Coronavirus disease 2019 (COVID-19) is

\section{Correspondence: Thomas Massarvva}

Department of Primary Care and Population Health, University of Nicosia Medical School, 93 Agiou Nikolaou Street, Nicosia 2408, Cyprus

E-mail: thomas.massarv@hotmail.com

Received: Apr 23, 2021 / Accepted: May 17, 2021 / Published: May 17, 2021

This article is available from: https://e-epih.org/

(c) This is an open-access article distributed under the terms of the Creative Commons Attribution License (https://creativecommons.org/licenses/by/4.0/), which permits unrestricted use, distribution, and reproduction in any medium, provided the original work is properly cited.

(C) 2021, Korean Society of Epidemiology the disease caused by SARS-CoV-2, which has resulted in severe morbidity and mortality of patients worldwide. As of December 18, 2020, the World Health Organization (WHO) has reported 73,275,943 confirmed cases of COVID-19 and 1,650,348 deaths [2]. The virus spreads directly through the infected person's droplets and body fluids, or indirectly through objects used by the infected person [3]. Its clinical characteristics range from asymptomatic to symptomatic, including respiratory disease and organ failure, leading to a substantial increase in morbidity and mortality [4].

Emerging evidence suggests that pre-existing comorbidities appear to be the driving force behind COVID-19 mortality. Amongst people with diabetes, obesity, hypertension, cardiovascular disease, respiratory diseases, stroke, dementia, chronic kidney disease, as well as old persons and immunocompromised patients, the risk of death from COVID-19 is increased [5]. Given that human im- 
munodeficiency virus (HIV) infection results in a reduced number of CD4 cells and abnormal immune responses, leading to a weakened immune system and vulnerability to various pathogens and opportunistic infections [6], concerns about the outcomes of COVID-19 in HIV patients were immediately raised and carefully considered.

Although some scholars have speculated that antiretroviral drugs may favour HIV patients due to their activity against SARSCoV-2 and other coronaviruses [7], there has been no evidence that HIV patients receiving certain antiretroviral drugs have an altered risk of COVID-19 infection and severity [8]. A recent study on the effectiveness of antiviral drugs has now directed focus on a drug known as tenofovir, which has been extensively used for HIV treatment and as pre-exposure prophylaxis for HIV prevention. The study found that tenofovir can bind to the RNAdependent RNA polymerase (RdRp) of SARS-CoV-2 and may therefore impair its function [9]. While this promising finding may be useful in future research, no treatment for COVID-19 has been found. Accordingly, researchers have been trying to provide a clearer insight into various aspects of COVID-19 outcomes in HIV patients. A study found that older age, late diagnosis, low CD4 cell count, and treatment-naive status were potential determinants of COVID-19 incidence amongst HIV patients [10]. Similarly, a study in China confirmed that advanced age and preexisting comorbidities, such as hypertension and diabetes, are associated with unfavourable outcomes and increased mortality from COVID-19 [11].

Despite the current urgency to obtain a clear understanding of COVID-19 outcomes in HIV patients, large-scale observational studies on disease severity, symptoms, multimorbidity, complications, and mortality of HIV and COVID-19 coinfected patients have not yet been conducted. Given the limited data on this subject, in July 2020, the Centers for Disease Control and Prevention asserted that older HIV patients and those who have pre-existing comorbidities might be at increased risk for severe illness [12]. In view of the uncertainties relating to COVID-19 in people living with HIV and the unexpected nature of the virus, special alertness towards HIV and COVID-19 coinfection is needed. This concern is consistent with the annual rise in HIV incidence, which increases the likelihood of patients becoming coinfected with COVID-19. Despite the limited data, this systematic literature review assembled existing data on the earliest and current reported cases to provide the basis for what is known and to present relevant findings. Therefore, this study identified and quantified different aspects of COVID-19 outcomes amongst HIV patients, including the proportion of various symptoms, severity, pre-existing comorbidities, recovery, death, and the most commonly prescribed antiretroviral drugs in HIV patients with COVID-19 coinfection.

\section{MATERIALS AND METHODS}

\section{Literature search}

The methods and design used in this study comply with the Cochrane Collaboration Handbook, MOOSE (Meta-Analyses of Observational Studies in Epidemiology) and are reported in accordance with the PRISMA (Preferred Reporting Items for Systematic Reviews and Meta-Analyses) guidelines [13] (Supplementary Material 1). The inclusion and exclusion criteria are summarized in Table 1.

\section{Information sources}

A thorough literature search was carried out using the following databases: Embase, MEDLINE, Scopus, and selected Internet sites (e.g., PubMed, Cochrane Collaborative Review Group on HIV Infection and acquired immunodeficiency syndrome [AIDS], and the Science Citation Index).

\section{Search strategy}

Certain keywords and terms obtained from a scoping search and acquired knowledge in the field were used in the phase of literature search. Two categories of the main keywords were used for the search, COVID-19 and HIV, and related study keywords and terms were searched accordingly.

(1) COVID-19: "severe acute respiratory syndrome coronavirus" OR "coronavirus" OR "SARS-CoV-2" OR "Coronavirus Disease” OR "2019-nCoV” OR "COVID 2019, (2) HIV: "human immunodeficiency virus" OR "Acquired Immunodeficiency Syndrome" OR "HIV" OR "AIDS" OR "HIV-1" OR "HIV-2", (3) (1) and (2), and (4) Limit (3) to humans only.

\section{Eligibility criteria}

Inclusion and exclusion criteria were used for the search (Table 1). Studies that did not meet the inclusion criteria or discussed different topics that did not contribute to the research were excluded.

Table 1. Inclusion and exclusion criteria for the search

\begin{tabular}{|c|c|c|}
\hline Characteristics & Inclusion criteria & Exclusion criteria \\
\hline Diagnosis & $\begin{array}{l}\text { Confirmed or probable diagnosis of COVID-19 amongst HIV } \\
\text { patients. }\end{array}$ & $\begin{array}{l}\text { Studies discussing environmental, economic, or social impacts } \\
\text { of COVID-19 on HIV patients }\end{array}$ \\
\hline Age (yr) & $>16$ & $<16$ \\
\hline Type of study & Studies in English language and no geographical restrictions & Pre-clinical studies and news reports, editorials, reviews \\
\hline Published date & Between Apr and Dec 2020 & Before Apr 2020 \\
\hline
\end{tabular}

COVID-19, coronavirus disease 2019; HIV, human immuno deficiency virus. 
Table 2. Characteristics of the included studies

\begin{tabular}{|c|c|c|c|c|}
\hline Study, country & Study design & Sample & Antiretroviral drugs & Findings and outcomes \\
\hline $\begin{array}{l}\text { Altuntas Aydin et al., } \\
2020 \text { [19] } \\
\text { Turkey }\end{array}$ & Case series & $\begin{array}{l}4 \text { HIV patients with } \\
\text { confirmed COVID-19 }\end{array}$ & $\begin{array}{l}3 \text { of the } 4 \text { patients were on ART; } \\
\text { all three patients received } \\
\text { NRTI (tenofovir-based } \\
\text { regimen/emtricitabine) and } \\
\text { INSTI (dolutegravir/ } \\
\text { elvitegravir) }\end{array}$ & $\begin{array}{l}\text { - Use of regular antiretroviral drugs and } \\
\text { suppression of viral load improved COVID-19 } \\
\text { outcomes amongst HIV patients } \\
\text { - Pre-existing comorbidities were an important } \\
\text { factor in the mortality of COVID-19/ } \\
\text { HIV-coinfected patients } \\
\text { - } 1 \text { death occurred due to untreated } \\
\text { comorbidities }\end{array}$ \\
\hline $\begin{array}{l}\text { Blanco et al., } \\
2020[20] \\
\text { Spain }\end{array}$ & Case series & $\begin{array}{l}\text { Of } 543 \text { confirmed } \\
\text { COVID- } 19 \text { cases, } \\
5 \text { patients were } \\
\text { HIV-positive }\end{array}$ & $\begin{array}{l}4 \text { patients were on } \mathrm{ART} \text {; } \\
2 \text { patients received PI } \\
\text { (darunavir-boosted } \\
\text { cobicistat), and } 2 \text { patients } \\
\text { received INSTI (dolutegravir) }\end{array}$ & $\begin{array}{l}\text { - COVID-19/HIV-coinfected patients had similar } \\
\text { symptoms of COVID-19 as the general } \\
\text { population } \\
\text { - } 4 \text { patients were cured and } 1 \text { remained in the } \\
\text { ICU at the end of the study }\end{array}$ \\
\hline $\begin{array}{l}\text { Childs et al., } \\
2020 \text { [21] } \\
\text { United Kingdom }\end{array}$ & Case series & $\begin{array}{l}18 \text { COVID-19/ } \\
\text { HIV-coinfected } \\
\text { patients }\end{array}$ & $\begin{array}{l}\text { All } 18 \text { patients were on ART; } \\
\text { all of them received NRTI, } \\
11 \text { received } \mathrm{PI}, 4 \text { received } \\
\text { NNRTI, and } 3 \text { received INSTI }\end{array}$ & $\begin{array}{l}\text { - Hospitalized patients with COVID-19 were } \\
\text { more likely to be of Black ethnicity and to } \\
\text { have a lower CD4 cell count } \\
\text { - } 5 \text { patients died, } 12 \text { patients recovered, and } \\
1 \text { patient remained in the hospital at the end } \\
\text { of the study }\end{array}$ \\
\hline $\begin{array}{l}\text { Del Amo et al., } \\
2020 \text { [22] } \\
\text { Spain }\end{array}$ & Cohort study & $\begin{array}{l}236 \text { COVID-19/ } \\
\text { HIV-coinfected } \\
\text { patients out of } \\
77,590 \text { HIV patients } \\
\text { receiving ART }\end{array}$ & $\begin{array}{l}\text { All COVID-19/HIV-coinfected } \\
\text { patients received NRTIs; } \\
21 \text { received TDF/FTC } \\
\text { (tenofovir disoproxil } \\
\text { fumarate/emtricitabine, } \\
100 \text { received TAF/FTC } \\
\text { (tenofovir alafenamide/ } \\
\text { emtricitabine), and } \\
57 \text { received ABC/3TC }\end{array}$ & $\begin{array}{l}\text { - } 151 \text { coinfected patients with COVID-19/HIV } \\
\text { were hospitalized and } 15 \text { were admitted to } \\
\text { the ICU } \\
\text { - The risk of diagnosis of COVID-19 was lower } \\
\text { in HIV patients ( } 30.0 \text { per 10,000) than in the } \\
\text { general population ( } 41.7 \text { per } 10,000 \text { ) } \\
\text { - This risk of diagnosis of COVID-19 was lower } \\
\text { among HIV patients who received TDF/FTC } \\
\text { - } 20 \text { patients died, of whom } 10 \text { were on } \\
\text { TAF/FTC, } 8 \text { were on ABC/3TC, and none were } \\
\text { on TDF/FTC }\end{array}$ \\
\hline $\begin{array}{l}\text { Etienne et al., } \\
2020 \text { [23] } \\
\text { France }\end{array}$ & Cohort study & $\begin{array}{l}54 \text { COVID-19/ } \\
\text { HIV-coinfected } \\
\text { patients }\end{array}$ & $\begin{array}{l}\text { All } 54 \text { patients were on ART; } \\
43 \text { patients received NRTI, } \\
33 \text { received INSTI, and } \\
25 \text { received NNRTI }\end{array}$ & $\begin{array}{l}\text { - COVID-19 severity in HIV patients was } \\
\text { associated with male sex, older age, and } \\
\text { metabolic disorders including diabetes } \\
\text { mellitus and obesity } \\
\text { - } 1 \text { patient died }\end{array}$ \\
\hline $\begin{array}{l}\text { Gervasoni et al., } \\
2020[24] \\
\text { Italy }\end{array}$ & Case series & $\begin{array}{l}\text { Of 6,000 HIV patients, } \\
47 \text { had proven or } \\
\text { probable COVID-19 } \\
\text { infection }\end{array}$ & $\begin{array}{l}80 \% \text { of COVID- } 19 / \\
\text { HIV-coinfected patients } \\
\text { received INSTI, } 11 \% \text { received } \\
\mathrm{PI} \text {, and } 42 \% \text { received NRTI }\end{array}$ & $\begin{array}{l}\text { - } 13 \text { COVID-19/HIV-coinfected patients were } \\
\text { hospitalized } \\
\text { - The risk of severe disease, death, and } \\
\text { admission to an ICU in COVID-19/ } \\
\text { HIV-coinfected patients compared favourably } \\
\text { with that seen in the entire population of } \\
\text { COVID-19 patients } \\
\text { - } 2 \text { deaths occurred }\end{array}$ \\
\hline $\begin{array}{l}\text { Gudipati et al., } \\
2020[25] \\
\text { USA }\end{array}$ & Case series & $\begin{array}{l}14 \text { HIV patients had } \\
\text { confirmed COVID-19 } \\
\text { infection from 7,372 } \\
\text { COVID-19 positive } \\
\text { tests }\end{array}$ & $\begin{array}{l}13 \text { of the } 14 \text { coinfected patients } \\
\text { received } A R T ; 12 \text { patients } \\
\text { received tenofovir-based } \\
\text { regimen (NRTI); one patient } \\
\text { received a PI-based regimen }\end{array}$ & $\begin{array}{l}\text { - } 8 \text { patients were hospitalized, and } \\
2 \text { patients were transferred to the ICU (both } \\
\text { of whom have pre-existing comorbidities) } \\
\text { - } 1 \text { patient died as a result of cardiac arrest } \\
\text { - Coinfected patients with COVID-19/HIV were } \\
\text { not at a higher risk of death or severe } \\
\text { outcomes than HIV-negative patients }\end{array}$ \\
\hline $\begin{array}{l}\text { Guo et al., } \\
2020[10] \\
\text { China }\end{array}$ & $\begin{array}{l}\text { Cross-sectional } \\
\text { study }\end{array}$ & $\begin{array}{l}11 \mathrm{HIV/} \\
\text { COVID-19-coinfected } \\
\text { patients }\end{array}$ & $\begin{array}{l}10 \text { HIV patients with COVID-19 } \\
\text { were on ART therapy; } \\
9 \text { patients received NRTI and } \\
\text { NNRTIs, } 1 \text { patient received } \\
\text { lopinavir/ritonavir (PI) }\end{array}$ & $\begin{array}{l}\text { - The incidence rate of COVID-19 in HIV } \\
\text { patients in Wuhan, China was comparable to } \\
\text { that of the entire population }(0.6 \%) \\
\text { - Those who were of older age and } \\
\text { treatment-naïve showed a marginal } \\
\text { association with contracting COVID-19 } \\
\text { - } 2 \text { deaths }\end{array}$ \\
\hline
\end{tabular}


Table 2. Continued

\begin{tabular}{|c|c|c|}
\hline Study, country & Study design & Sample \\
\hline $\begin{array}{l}\text { Härter et al., } \\
2020 \text { [26] } \\
\text { Germany }\end{array}$ & Case series & $\begin{array}{l}33 \text { COIVID-19/ } \\
\text { HIV-coinfected } \\
\text { patients }\end{array}$ \\
\hline $\begin{array}{l}\text { Hu et al., } \\
2020 \text { [27] } \\
\text { China }\end{array}$ & Case series & $\begin{array}{l}\text { Of 2,900 HIV patients, } \\
12 \text { COVID-19/ } \\
\text { HIV-coinfected } \\
\text { patients }\end{array}$ \\
\hline $\begin{array}{l}\text { Huang et al., } \\
2020 \text { [28] } \\
\text { China }\end{array}$ & Cohort study & $\begin{array}{l}35 \text { of } 6,001(0.6 \%) \\
\text { HIV patients had } \\
\text { COVID-19 }\end{array}$ \\
\hline
\end{tabular}

All patients were on ART; $31 / 33$
received NRTIs, 20 received
INSTI and 9 received NNRTI

- 91\% of all COVID-19/HIV patients recovered and $76 \%$ were classified as mild cases

- 3/32 patients died (9.3\%), of whom 1 patient was $82 \mathrm{yr}$ old, the second patient had a CD4 cell count below $200 / \mathrm{mm}^{3}$, and the third patient suffered from several comorbidities

9 COVID-19/HIV patients received $A R T$; all of them received NRTI and NNRTI

28/35 (80.0\%) were on continued ART; 4 patients (11.4\%) had discontinued their ART therapy; 32/35 $(91.4 \%)$ received NRTl; 30/35 $(80.5 \%)$ received NNRTI
- Late initiation of ART among HIV patients could lead to more severe symptoms

-1 patient died

- The incidence, case-fatality, and severity rates of COVID-19 in HIV patients were comparable to those in the entire population

- COVID-19 incidence amongst HIV patients on ART was lower than those who had discontinued therapy or were treatment-naive

- The COVID-19 incidence rate amongst HIV patients aged $50 \mathrm{yr}$ or above was 3 times higher than amongst HIV patients younger than $50 \mathrm{yr}$

- 2/35 deaths of patients coinfected with COVID-19/HIV in compared to $3,869 / 50,333$ in the entire population

$\begin{array}{ccc}\begin{array}{c}\text { Liu et al., } \\ 2020[29] \\ \text { China }\end{array} & \begin{array}{c}\text { Retrospective } \\ \text { cohort study }\end{array} & \begin{array}{c}20 \text { COVID-19/ } \\ \text { HIV-coinfected } \\ \text { patients }\end{array} \\ & & \\ & & \\ \text { Meyerowitz et al., } & \begin{array}{c}\text { Cohort-based } \\ \text { study }\end{array} & \begin{array}{c}36 \text { patients living with } \\ \text { HIV were diagnosed }\end{array} \\ \text { USA } 2020] & & \text { with COVID-19 }\end{array}$

12 of 20 patients were on ART and 8 patients were treatment-naive; all 12 patients received NRTIs; 8 of them were on Pls, mainly - 1 death: an old man with pre-existing

lopinavir/ritonavir, and 6 were comorbidities on NNRTI (efavirenz)

35 patients were on ART; 29/35 received INSTI; 9 received $\mathrm{NNRTI}, 4$ received $\mathrm{PI}$, and 30 received NRTI

- Most COVID-19/HIV-coinfected patients (85\%) presented with mild to moderate symptoms, which may be associated with ART history in HIV patients

- 58\% of COVID-19/HIV-coinfected patients including 8 severe and 7 critical cases required hospitalization

- 30 patients (83.3\%) had severe illness associated with pre-existing comorbidities

- 2 patients $(5.6 \%)$ died

\begin{tabular}{|c|c|c|}
\hline $\begin{array}{l}\text { Nagarakanti et al., } \\
2021 \text { [31] } \\
\text { USA }\end{array}$ & $\begin{array}{l}\text { Retrospective } \\
\text { cohort study }\end{array}$ & $\begin{array}{l}23 \text { COVID-19/ } \\
\text { HIV-coinfected } \\
\text { patients }\end{array}$ \\
\hline $\begin{array}{l}\text { Sasset et al., } \\
2020 \text { [32] } \\
\text { Italy }\end{array}$ & Case series & $\begin{array}{l}2 \text { COVID-19/ } \\
\text { HIV-coinfected } \\
\text { patients }\end{array}$ \\
\hline
\end{tabular}

$35 \%$ of patients received INSTI, $22 \%$ received NNRTI, and $26 \%$ received a combination of INSTI and PI

- Clinical outcomes were similar between COVID-19/HIV-coinfected patients and COVID-19 patients without HIV

- 3 patients died

Both patients received INSTI and PI

- Both patients suffered from several comorbidities

- 1 patient recovered and the second was still in the ICU at the end of this report

- Only $0.15 \%$ of the total HIV population showed COVID-19 symptoms

\begin{tabular}{|c|c|c|c|}
\hline $\begin{array}{l}\text { SeyedAlinaghi et al., } \\
2020 \text { [33] } \\
\text { Iran }\end{array}$ & $\begin{array}{l}\text { Cross-sectional } \\
\text { study }\end{array}$ & $\begin{array}{l}\text { Of } 200 \text { HIV patients, } \\
\text { one patient had } \\
\text { COVID-19 }\end{array}$ & $\begin{array}{l}\text { The patient received lopinavir/ } \\
\text { ritonavir (PI) and Truvada } \\
\text { (NRTI) }\end{array}$ \\
\hline
\end{tabular}

- Symptoms resolved in $1 \mathrm{wk}$

- HIV-positive patients and/or patients receiving ART may have a lower susceptibility to becoming infected with COVID-19 or have a decreased severity of the disease

\begin{tabular}{|c|c|c|}
\hline $\begin{array}{l}\text { Sigel et al., } \\
2020 \text { [34] }\end{array}$ & Cohort study & $\begin{array}{l}\text { Of } 439 \text { COVID-19 } \\
\text { patients, } 88 \text { were }\end{array}$ \\
\hline USA & & coinfected with $\mathrm{H}$ \\
\hline
\end{tabular}

All 88 coinfected patients were on ART; 85 patients received NRTI, 69 received INSTI, and 15 received $\mathrm{PI}$
- During the follow-up period, most COVID-19/ HIV patients were discharged from the hospital
- 18 patients died, most of whom had comorbidities such diabetes, hypertension, and chronic kidney disease


Table 2. Continued

\begin{tabular}{|c|c|c|c|c|}
\hline Study, country & Study design & Sample & Antiretroviral drugs & Findings and outcomes \\
\hline $\begin{array}{l}\text { Stoeckle et al., } \\
2020 \text { [35] } \\
\text { USA }\end{array}$ & $\begin{array}{l}\text { Retrospective } \\
\text { cohort study }\end{array}$ & $\begin{array}{l}30 \text { COVID-19/ } \\
\text { HIV-coinfected } \\
\text { patients (case group) } \\
\text { matched with } 90 \\
\text { COVID-19 patients } \\
\text { without HIV (control } \\
\text { group) }\end{array}$ & $\begin{array}{l}\text { 29/30 patients were on ART; } \\
9 \text { patients received } \mathrm{PI} \\
\text { (lopinavir/ritonavir) and } \\
19 \text { received NRTI }\end{array}$ & $\begin{array}{l}\text { - Symptoms and laboratory findings were } \\
\text { similar between cases and controls } \\
\text { - Immunity suppression in HIV patients may } \\
\text { result in less severe forms of COVID-19 and } \\
\text { potentially favourable outcomes } \\
\text { - No deaths }\end{array}$ \\
\hline $\begin{array}{l}\text { Swaminathan et al., } \\
2021[36] \\
\text { USA }\end{array}$ & Case series & $\begin{array}{l}6 \text { COVID-19/ } \\
\text { HIV-coinfected } \\
\text { patients }\end{array}$ & $\begin{array}{l}5 / 6 \text { patients received } A R T \text {; the } \\
\text { majority of the patients were } \\
\text { on INSTIs }\end{array}$ & $\begin{array}{l}\text { - Some data suggests that the protective } \\
\text { effect of antiretroviral drugs could result in } \\
\text { a favourable outcome of COVID-19 in HIV } \\
\text { patients } \\
\text { - } 2 \text { deaths (both had multiple medical } \\
\text { comorbidities) }\end{array}$ \\
\hline $\begin{array}{l}\text { Tian et al., } \\
2021[37] \\
\text { China }\end{array}$ & Case report & $\begin{array}{l}1 \mathrm{HIV} / \\
\text { COVID-19-coinfected } \\
\text { patient }\end{array}$ & $\begin{array}{l}\text { The patient received lopinavir/ } \\
\text { ritonavir (PI) }\end{array}$ & $\begin{array}{l}\text { - HIV patients who received regular } \\
\text { antiretroviral drugs had no severe outcomes } \\
\text { or a poor prognosis of COVID-19 } \\
\text { - No deaths }\end{array}$ \\
\hline $\begin{array}{l}\text { Vizcarra et al., } \\
2020[38] \\
\text { Spain }\end{array}$ & Cohort study & $\begin{array}{l}51 \text { of } 1,339 \text { HIV } \\
\text { patients were } \\
\text { diagnosed with } \\
\text { COVID-19 }\end{array}$ & $\begin{array}{l}37(73 \%) \text { COVID-19/ } \\
\text { HIV-coinfected patients } \\
\text { received NRTI and } 41(80 \%) \\
\text { received INSTI }\end{array}$ & $\begin{array}{l}\text { - Of all coinfected cases, } 44 \text { patients recovered } \\
\text { - Previous use of NRTIs or PIs was not } \\
\text { associated with differences in the clinical } \\
\text { presentation } \\
\text { - } 2 \text { deaths }\end{array}$ \\
\hline $\begin{array}{l}\text { Yang et al., } \\
2021[39] \\
\text { China }\end{array}$ & $\begin{array}{l}\text { Case-control } \\
\text { study }\end{array}$ & $\begin{array}{l}3 \text { COVID-19/ } \\
\text { HIV-coinfected } \\
\text { patients (case group) } \\
53 \text { COVID-19 patients } \\
\text { without HIV (control } \\
\text { group) }\end{array}$ & $\begin{array}{l}\text { All coinfection patients } \\
\text { received ART; } 2 \text { patients } \\
\text { received NRTI and NNRTI; } \\
\text { the third patient received } \\
\text { NRTI INSTI, NNRTI }\end{array}$ & $\begin{array}{l}\text { - The effects of antiretroviral drugs in the } \\
\text { prevention and treatment of COVID-19 may } \\
\text { be favourable, but seem to be limited } \\
\text { - No deaths }\end{array}$ \\
\hline
\end{tabular}

COVID-19, coronavirus disease 2019; HIV, human immunodeficiency virus; ART, antiretroviral therapy; NRTI, nucleoside reverse transcriptase inhibitor; NNRTI, non-nucleoside reverse transcriptase inhibitor; PI, protease inhibitor; INSTI, integrase strand transfer inhibitor; ICU, intensive care unit; TDF, tenofovir disoproxil fumarate; FTC, emtricitabine; TAF, tenofovir alafenamide; ABC, abacavir; 3TC, lamivudine.

\section{Data extraction}

Data were extracted using a standardized form and the assessment was carried out by classifying studies as eligible, non-eligible, or possibly eligible according to the eligibility and inclusion criteria [14]. A study was assessed for eligibility if its title and abstract were relevant and could not be excluded, and the process was based on the approval of the supervisor (Romero, R). In order to examine the data for consistency and clarity or in case of disagreement on the inclusion of studies, a third reviewer could be appointed to assess eligibility independently. The following data were extracted: sample size, study design, population characteristics (age, sex, CD4 cell count, viral load), used antiretroviral drugs, outcome (recovery, death, still in hospital), severity (mild, moderate, severe/critical) and related comorbidities (e.g., diabetes mellitus, hypertension, cardiovascular diseases, respiratory diseases, chronic kidney disease, obesity). Where necessary, authors were asked to provide the raw data or additional information.

\section{Quality assessment}

The quality and risk of bias assessment was carried out using the Newcastle-Ottawa Quality Scale [15], which includes 8 customized assessment sheet criteria that are categorised into 3 groups: selection, comparability, and outcome. The assessment sheet evaluated the representativeness of cases, research methods and the outcomes of each study. Quality assessment was conducted using different criteria based on various study designs. A score between 1 and 3 out of 8 implies a higher risk of bias due to inadequacy of reporting, the use of invalid and unreliable measures to define conditions and exposures, mis-representativeness of cases, unclear population characteristics, unblinded assessors, and insufficient follow-up of cases. Medium-risk studies scored 4-5 out of 8 and lower-risk studies scored 6-8 out of 8 (Supplementary Material 2).

\section{Data synthesis}

Data from the included studies were tabulated and categorized based on the study sample, comorbidities, recovery, severity, antiretroviral drug use, and other factors influencing the total number of patients. Accordingly, a descriptive analysis was used to report findings, and bar charts were used to display key findings. Stata version 16.0 (Stata Corp., College Station, TX, USA) was used for the analysis.

Unfortunately, due to a lack of data and variability in the comparison groups amongst the included studies, a meta-analysis for comparison between groups could not be performed. However, 
when data permitted, a meta-analysis of proportions was conducted by calculating the pooled estimate of the proportion of recovery amongst patients with HIV/COVID-19 coinfection, using a random-effects model [16]. The meta-analysis of proportions was performed using the "metafor" package in R version 4.0.3 (R Foundation for Statistical Computing, Vienna, Austria). Data were weighted prior to combination to account for the various samples from different studies and to avoid pooling the data as if they were derived from a single sample.

A random-effects analysis was used, with a binomial distribution modelling within-study variability and parameters estimated using a maximum likelihood procedure. To calculate the confidence intervals (CIs) for between-study variance, the Jackson [17] method was used. The overall proportions were shown, along with $95 \%$ CIs. The I ${ }^{2}$ statistic was used to report between-study heterogeneity, and the p-value confirmed the result.

\section{Publication bias assessment}

Publication bias was assessed using funnel plots, and the degree of asymmetry was tested using Egger's regression test [18]. Both analyses were performed in R using the "metafor" package.

\section{Ethics statement}

As the present study was a systematic review, no ethics statement was needed.

\section{RESULTS}

\section{Study selection}

A total of 632 articles were found. Following the PRISMA guidelines, 247 duplicate articles were excluded and after screening titles and abstracts, 339 additional articles were excluded. Only 22 of the studies were included for analysis after full-text screening of 44 articles.

All 22 included articles were observational studies, of which there were 9 cohort studies (including 3 retrospective studies), 9 case series, 2 cross-sectional studies, 1 case-control study, and 1 case report. Figure 1 shows a PRISMA flow chart that explains the inclusion and exclusion process for this systematic literature review.

\section{Study characteristics}

The finally selected studies were listed according to the first author, publication year, country, study design, sample, antiretroviral drugs, findings, and outcomes. The study characteristics are detailed in Table 2 [10,19-39]. All of the selected studies were observational studies that provided data on the outcomes of COVID-19 amongst HIV patients, clinical outcomes amongst antiretroviral therapy (ART) users, demographic data, and severity determinants in coinfected cases. Six studies were conducted in the United States, 6 in China, 3 in Spain, 2 in Italy, and the remaining 5 studies were conducted in France, Germany, United Kingdom, Turkey, and Iran. All of the studies were conducted between April

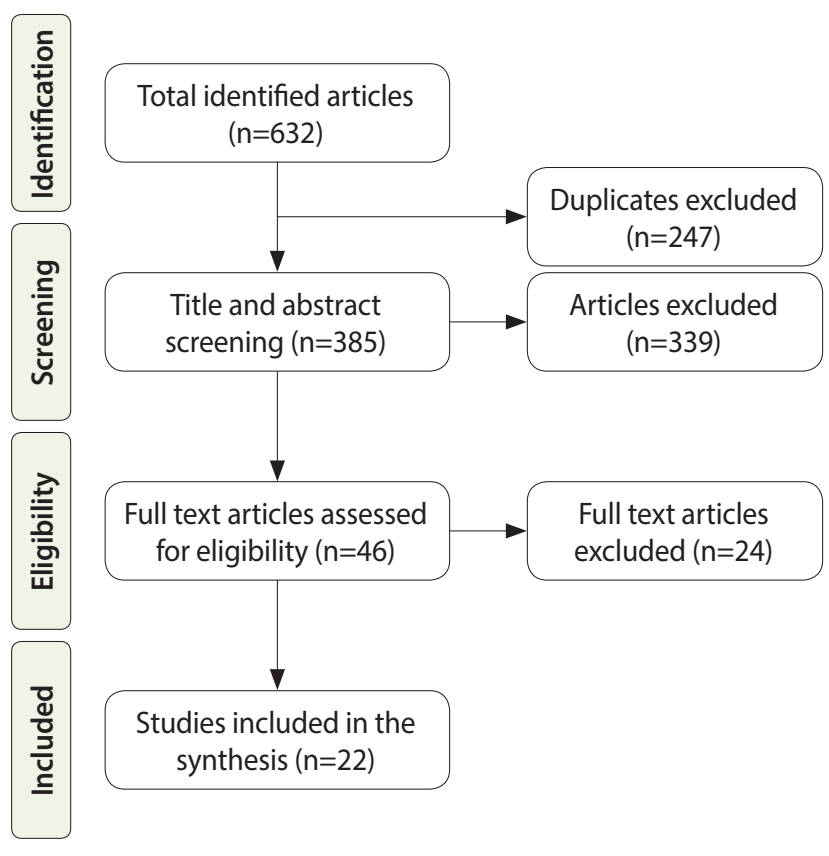

Figure 1. PRISMA (Preferred Reporting Items for Systematic Reviews and Meta-analysis) flow chart of search and study selection.

15, 2020 and November 17, 2020. An overview of the included studies is provided in Table 3 [10,19-39].

\section{Quality and risk of bias within studies}

The quality of studies and risk of bias were reported using the Newcastle-Ottawa Scale following approval from the supervisor (Romero, R). Although all of the included studies are observational, different criteria were customised to assess the quality and bias within studies based on the study design. The assessment was carried out using a rating scale ranging from 1 to 8 out of 8 . A higher score implies a lower risk of bias due to adequacy of reporting, the use of valid and reliable measures to define conditions and exposures, representativeness of cases, presence of nonexposed in cohorts, clarity of characteristics, blinding assessors, sufficient follow-up of cases, and clear outcomes. None of the included studies scored lower than 4 , and therefore none were classified as high-risk studies. Where certain data were missing and no additional information could be received from the authors, the ratings were classified as "unknown" (Supplementary Material 2).

\section{Synthesis of results}

The synthesis of results from different observational study designs across outcomes of COVID-19 amongst HIV patients is provided in Table 4. Overall, 730 HIV patients with COVID-19 coinfection were reported in all studies. The patients were predominantly male (79.4\%) and the mean age of all reported cases was 49.11 years. A low CD4 cell count $\left(<200\right.$ cells $\left./ \mathrm{mm}^{3}\right)$ was reported in 87 of 470 patients (18.5\%) and the viral load was higher than 50 copies $/ \mathrm{mL}$ in 41 of 393 patients (10.4\%). The number of 
Table 3. Overview of the population characteristics from observational studies

\begin{tabular}{|c|c|c|c|c|c|c|c|c|c|}
\hline Study & $\begin{array}{l}\text { Sample } \\
\text { (COVID-19/ } \\
\text { HIV-coinfected } \\
\text { patients), } n\end{array}$ & $\begin{array}{l}\text { Age } \\
\text { (mean), } \\
\text { yr }\end{array}$ & Sex, $n$ & $\begin{array}{l}\text { CD4 cell } \\
\text { count, } \\
(>200 \text { cells/ } \\
\left.\mathrm{mm}^{3}\right) \mathrm{n}\end{array}$ & $\begin{array}{l}\text { HIV viral } \\
\text { load, }(<50 \\
\text { copies/ } \\
\text { mL) n }\end{array}$ & $\begin{array}{l}\text { Severe/ } \\
\text { critical } \\
\text { cases, } \mathrm{n}\end{array}$ & Comorbidities & Symptoms & $\begin{array}{l}\text { Antiretroviral } \\
\text { drugs }\end{array}$ \\
\hline $\begin{array}{l}\text { Altuntas Aydin } \\
\text { et al., } 2020 \text { [19] }\end{array}$ & 4 & 37.2 & M: 4 & 3 & 3 & 1 & $\begin{array}{l}\text { HTN, DM, } \\
\quad B M I>30 \mathrm{~kg} / \mathrm{m}^{2}\end{array}$ & $\begin{array}{l}\text { Fever, cough, } \\
\text { dyspnoea }\end{array}$ & NRTI, INSTI \\
\hline $\begin{array}{l}\text { Blanco et al., } \\
2020 \text { [20] }\end{array}$ & 5 & 37.8 & $M: 3, F: 2$ & 5 & 4 & 2 & $\begin{array}{l}\text { Hypothyroidism, } \\
\text { asthma }\end{array}$ & $\begin{array}{l}\text { Fever, cough, } \\
\text { dyspnoea }\end{array}$ & PI, INSTI \\
\hline $\begin{array}{l}\text { Childs et al., } \\
2020 \text { [21] }\end{array}$ & 18 & 52.0 & M: 12, F: 6 & 18 & 17 & 5 & $\begin{array}{l}\text { HTN, DM, RD, } \\
\mathrm{BMl}>30 \mathrm{~kg} / \mathrm{m}^{2}\end{array}$ & $\begin{array}{l}\text { Fever, cough, } \\
\text { dyspnoea }\end{array}$ & $\begin{array}{l}\text { NRTI, NNRTI, } \\
\text { PI, INSTI }\end{array}$ \\
\hline $\begin{array}{l}\text { Del Amo et al., } \\
2020 \text { [22] }\end{array}$ & 236 & 47.0 & M: 204, F: 32 & $U$ & U & 15 & $\mathrm{U}$ & U & $\begin{array}{l}\text { NRTI, NNRTI, } \\
\text { PI, INSTI }\end{array}$ \\
\hline $\begin{array}{l}\text { Etienne et al., } \\
2020 \text { [23] }\end{array}$ & 54 & 54.0 & M: 33, F: 21 & 51 & 51 & 19 & $\begin{array}{l}\text { HTN, DM, RD, CVD, } \\
\text { RPD, LD, neoplasm, } \\
\text { BMl }>30 \mathrm{~kg} / \mathrm{m}^{2}\end{array}$ & $\mathrm{U}$ & $\begin{array}{l}\text { NRTI, NNRTI, } \\
\text { PI, INSTI }\end{array}$ \\
\hline $\begin{array}{l}\text { Gervasoni et al., } \\
2020 \text { [24] }\end{array}$ & 47 & 51.0 & M: 36, F: 11 & 36 & 44 & 6 & $\begin{array}{l}\text { HTN, DM, RD, CVD, } \\
\text { LD, RPD, neoplasm }\end{array}$ & $\begin{array}{l}\text { Fever, cough, } \\
\text { dyspnoea }\end{array}$ & $\begin{array}{l}\text { NRTI, PI, } \\
\text { INSTI }\end{array}$ \\
\hline $\begin{array}{l}\text { Gudipati et al., } \\
2020 \text { [25] }\end{array}$ & 14 & 49.0 & $M: 12, F: 2$ & 12 & 13 & 2 & $\begin{array}{l}\text { HTN, DM, RD, CVD, } \\
\text { RPD, BMl }>30 \mathrm{~kg} / \mathrm{m}^{2}\end{array}$ & $\begin{array}{l}\text { Fever, cough, } \\
\text { dyspnoea }\end{array}$ & NRTI, PI \\
\hline $\begin{array}{l}\text { Guo et al., } \\
2020 \text { [10] }\end{array}$ & 11 & 53.2 & M: 10, F: 1 & 9 & 9 & 5 & $\begin{array}{l}6 \text { cases with } \\
\text { comorbidities }\end{array}$ & $U$ & $\begin{array}{l}\text { NRTI, NNRTI, } \\
\text { PI }\end{array}$ \\
\hline $\begin{array}{l}\text { Härter et al., } \\
2020 \text { [26] }\end{array}$ & 33 & 48.0 & $\mathrm{M}: 30, \mathrm{~F}: 3$ & 31 & 30 & 8 & $\begin{array}{l}\text { HTN, DM, RD, CVD, } \\
\text { RPD, LD }\end{array}$ & $\begin{array}{l}\text { Fever, cough, } \\
\text { dyspnoea }\end{array}$ & $\begin{array}{c}\text { NRTI, NNRTI, } \\
\text { PI, INSTI }\end{array}$ \\
\hline $\begin{array}{l}\text { Hu et al., } \\
2020 \text { [27] }\end{array}$ & 12 & 36.0 & M: 10, F: 2 & 12 & 8 & 2 & HTN, RD, RPD & $\mathrm{U}$ & NRTI, NNRTI \\
\hline $\begin{array}{l}\text { Huang et al., } \\
2020 \text { [28] }\end{array}$ & 35 & 52.0 & $M ; 33, F: 2$ & 30 & 22 & 15 & $U$ & U & NRTI, NNRTI \\
\hline $\begin{array}{l}\text { Liu et al., } \\
2020 \text { [29] }\end{array}$ & 20 & 46.5 & M: 5, F: 15 & $U$ & U & 3 & $\begin{array}{l}\text { HTN, DM, CVD, RPD, } \\
\text { LD }\end{array}$ & $\begin{array}{l}\text { Fever, cough, } \\
\text { dyspnoea }\end{array}$ & $\begin{array}{l}\text { NRTI, NNRTI, } \\
\text { PI }\end{array}$ \\
\hline $\begin{array}{l}\text { Meyerowitz } \\
\text { et al., } 2020 \text { [30] }\end{array}$ & 36 & 53.4 & U & 34 & $U$ & 15 & $\begin{array}{l}\text { HTN, DM, RD, } \\
\text { BMl }>30 \mathrm{~kg} / \mathrm{m}^{2}\end{array}$ & U & $\begin{array}{c}\text { NRTI, NNRTI, } \\
\text { PI, INSTI }\end{array}$ \\
\hline $\begin{array}{l}\text { Nagarakanti } \\
\text { et al., } 2021 \text { [31] }\end{array}$ & 23 & 59.0 & M: 14, F: 9 & 20 & U & 2 & $\begin{array}{l}\text { HTN, DM, RD, CVD, } \\
\text { RPD }\end{array}$ & $\begin{array}{l}\text { Fever, cough, } \\
\text { dyspnoea }\end{array}$ & $\begin{array}{l}\text { NRTI, NNRTI, } \\
\text { PI, INSTI }\end{array}$ \\
\hline $\begin{array}{l}\text { SeyedAlinaghi } \\
\text { et al., } 2020 \text { [33] }\end{array}$ & 1 & 40.5 & M: 1 & $\mathrm{~N}$ & 1 & $\mathrm{~N}$ & $\mathrm{~N}$ & $\begin{array}{l}\text { Fever, cough, } \\
\text { dyspnoea }\end{array}$ & NRTI, PI \\
\hline $\begin{array}{l}\text { Sigel et al., } \\
2020 \text { [34] }\end{array}$ & 88 & 61.0 & M: 66, F: 22 & 64 & 66 & 18 & $\begin{array}{l}\mathrm{HTN}, \mathrm{DM}, \mathrm{RD}, \mathrm{LD}, \\
\mathrm{RPD}, \text { neoplasm, } \\
\mathrm{BMI}>30 \mathrm{~kg} / \mathrm{m}^{2}\end{array}$ & U & $\begin{array}{l}\text { NRTI, NNRTI, } \\
\text { PI, INSTI }\end{array}$ \\
\hline $\begin{array}{l}\text { Stoeckle et al., } \\
2020 \text { [35] }\end{array}$ & 30 & 60.5 & M: 24, F: 6 & 20 & 27 & 4 & $\begin{array}{l}\text { HTN, DM, RD, CVD, } \\
\text { LD, RPD, }\end{array}$ & $\begin{array}{l}\text { Fever, cough, } \\
\text { dyspnoea }\end{array}$ & NRTI, PI \\
\hline $\begin{array}{l}\text { Sasset et al., } \\
2020 \text { [32] }\end{array}$ & 2 & 61.2 & M: 2 & 2 & 2 & 2 & $\begin{array}{l}\text { HTN, CVD, LD, } \\
\mathrm{BMI}>30 \mathrm{~kg} / \mathrm{m}^{2}\end{array}$ & U & $\mathrm{PI}$ \\
\hline $\begin{array}{l}\text { Swaminathan } \\
\text { et al., } 2021 \text { [36] }\end{array}$ & 6 & 64.0 & $\mathrm{M}: 5, \mathrm{~F}: 1$ & 6 & 5 & 2 & $\begin{array}{l}\text { HTN, DM, RD, CVD, } \\
\text { RPD, BMl }>30 \mathrm{~kg} / \mathrm{m}^{2}\end{array}$ & U & INSTI \\
\hline $\begin{array}{l}\text { Tian et al., } \\
2021 \text { [37] }\end{array}$ & 1 & 24.0 & M: 1 & 1 & U & $\mathrm{N}$ & U & U & $\mathrm{PI}$ \\
\hline $\begin{array}{l}\text { Vizcarra et al., } \\
2020 \text { [38] }\end{array}$ & 51 & 53.3 & M: 43, F: 8 & 27 & 50 & 6 & $\begin{array}{l}\text { HTN, DM, RD, CVD, } \\
\text { LD, RPD, neoplasm, } \\
\text { BMl }>30 \mathrm{~kg} / \mathrm{m}^{2}\end{array}$ & $\begin{array}{l}\text { Fever, cough, } \\
\text { dyspnoea }\end{array}$ & $\begin{array}{l}\text { NRTI, NNRTI, } \\
\text { PI, INSTI }\end{array}$ \\
\hline $\begin{array}{l}\text { Yang et al., } \\
2021 \text { [39] }\end{array}$ & 3 & 40.0 & M: 3 & 2 & U & $\mathrm{N}$ & $U$ & U & $\begin{array}{l}\text { NRTI, NNRTI, } \\
\text { INSTI }\end{array}$ \\
\hline
\end{tabular}

U, unknown; N, null; HTN, hypertension; DM, diabetes mellitus; RD, renal disease; CVD, cardiovascular disease; BMI, body mass index; LD, liver disease; RPD, respiratory disease; NRTI, nucleoside reverse transcriptase inhibitor; NNRTI, non-nucleoside reverse transcriptase inhibitor; PI, protease inhibitor; INSTI, integrase strand transfer inhibitor; $M$, male; F, female. 
Table 4. Demographic and clinical characteristics of COVID-19 infection in people living with HIV included in the reviewed studies (total patients $=730$ )

\begin{tabular}{|c|c|}
\hline Characteristics & $\mathrm{N}(\%)$ \\
\hline Age (mean \pm SD/median) & $49.11 \pm 9.94 / 51.5$ \\
\hline \multicolumn{2}{|l|}{$\operatorname{Sex}(n=694)$} \\
\hline Male & $551(79.4)$ \\
\hline Female & $143(20.6)$ \\
\hline \multicolumn{2}{|l|}{ Used antiretroviral drugs $(n=728)$} \\
\hline Yes & $708(97.2)$ \\
\hline No & $22(2.7)$ \\
\hline \multicolumn{2}{|l|}{ CD4 cell count $(n=470)$} \\
\hline$<200 / \mathrm{mm}^{3}(\mathrm{~ns}=20)$ & $87(18.5)$ \\
\hline$\geq 200 / \mathrm{mm}^{3}$ (ns=20) & $383(81.5)$ \\
\hline \multicolumn{2}{|l|}{ HIV viral load $(n=393)$} \\
\hline$<50$ copies/mL (ns=16) & $352(89.6)$ \\
\hline$>50$ copies $/ \mathrm{mL}(\mathrm{ns}=15)$ & $41(10.4)$ \\
\hline \multicolumn{2}{|l|}{ Severity $(n=728)$} \\
\hline Mild-moderate & $596(81.9)$ \\
\hline Severe-critical & $132(18.1)$ \\
\hline \multicolumn{2}{|l|}{ Clinical outcome $(n=720)$} \\
\hline Death & $68(9.4)$ \\
\hline Recovery & $652(90.6)$ \\
\hline \multicolumn{2}{|l|}{ ART regimen } \\
\hline NRTI & $543(44.6)$ \\
\hline NNRTI & $161(13.2)$ \\
\hline $\mathrm{PI}$ & $119(9.8)$ \\
\hline INSTI & $395(32.4)$ \\
\hline \multicolumn{2}{|l|}{ Comorbidities } \\
\hline Hypertension (ns=16) & $128(26.3)$ \\
\hline Body mass index $>30 \mathrm{~kg} / \mathrm{m}^{2}(\mathrm{~ns}=10)$ & $72(14.8)$ \\
\hline Diabetes mellitus ( $\mathrm{ns}=17$ ) & $61(12.5)$ \\
\hline Renal disease/CKD/ESRD (ns=17) & $59(12.1)$ \\
\hline Cardiovascular disease $(\mathrm{ns}=17)$ & $56(11.5)$ \\
\hline Neoplasm (ns=17) & $16(3.3)$ \\
\hline Liver disease $(\mathrm{ns}=17)$ & $49(10.1)$ \\
\hline Respiratory disease $(n s=17)$ & $45(9.3)$ \\
\hline \multicolumn{2}{|l|}{ Symptoms $(n=453)$} \\
\hline Cough $(n s=11)$ & $171(37.7)$ \\
\hline Fever $(n s=11)$ & $170(37.5)$ \\
\hline Dyspnoea (ns=11) & $112(24.7)$ \\
\hline
\end{tabular}

COVID-19, coronavirus disease 2019; HIV, human immunodeficiency virus; $\mathrm{N}$, number of the variable; $\mathrm{n}$, number of reported cases; ns, number of analysed studies; SD, standard deviation; ART, antiretroviral therapy; NRTI, nucleoside reverse transcriptase inhibitor; NNRTI, non-nucleoside reverse transcriptase inhibitor; PI, protease inhibitor; INSTI, integrase strand transfer inhibitor; CKD, chronic kidney disease; ESRD, end-stage renal disease.

reported patients receiving antiretroviral drugs was 708, representing $97.2 \%$ of all cases, and only 22 patients were treatmentnaive.

While $81.9 \%$ of coinfected patients had mild to moderate

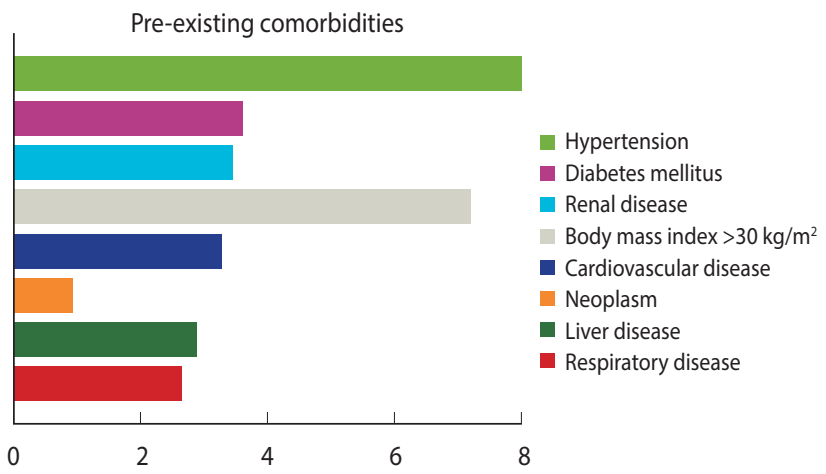

Figure 2. Mean proportion of patients with different comorbidities in the included studies.

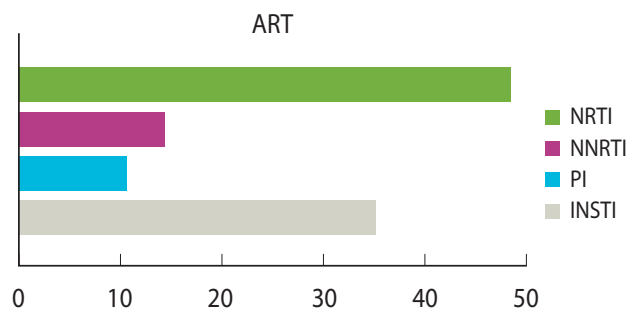

Figure 3. Mean proportion of patients receiving different antiretroviral medications in the included studies. ART, antiretroviral therapy; NRTI, nucleoside reverse transcriptase inhibitor; NNRTI, non-nucleoside reverse transcriptase inhibitor; Pl, protease inhibitor; INSTI, integrase strand transfer inhibitor.

symptoms of COVID-19, severe symptoms were diagnosed in $18.1 \%$ of the cases. The pre-existing comorbidities associated with HIV/COVID-19-coinfected patients were hypertension (26.3\%, 128 patients, 16 studies), body mass index greater than $30 \mathrm{~kg} / \mathrm{m}^{2}$ (14.8\%, 72 patients, 10 studies), diabetes mellitus (12.5\%, 61 patients), renal diseases (12.1\%), cardiovascular diseases (11.5\%) and liver disease (10.1\%) (Figure 2 and Table 4). Only 11 studies reported symptoms of COVID-19 amongst HIV patients. The most common symptoms were cough (37.7\%), fever (37.5\%), and dyspnoea (24.7\%). Of the 720 reported cases, $90.6 \%$ recovered and $9.4 \%(n=68)$ died. The antiretroviral regimens were grouped into 4 subcategories (nucleoside reverse transcriptase inhibitors [NRTIs], non-nucleoside reverse transcriptase inhibitors [NNRTIs], protease inhibitors [PI], and integrase strand transfer inhibitors [INSTIs]). At the time of diagnosis, a significantly higher proportion of individuals with COVID-19 (44.6\%) received a tenofovir-based regimen (NRTI), while $32.4 \%$ received INSTI (Figure 3 and Table 4).

When data allowed, the meta-analysis of proportions included all 22 studies to estimate the recovery proportion of HIV/COVID-19-coinfected patients. None of the included studies were excluded from the analysis due to the low-medium risk of bias (scored $4-8)$. The pooled recovery proportion of HIV/COVID-19 coinfection was $87 \%$ (95\% CI, 83 to 91), as shown in Figure 4. The weight- 
Study

$\begin{array}{lrr}\text { Altuntas Aydin et al 2020 } & 3 & 4 \\ \text { Blanco et al 2020 } & 5 & 5 \\ \text { Childs et al 2020 } & 13 & 18 \\ \text { Del Amo et al 2020 } & 216 & 236 \\ \text { Etienne et al 2020 } & 53 & 54 \\ \text { Gervasoni et al 2020 } & 45 & 47 \\ \text { Gudipati et al 2020 } & 13 & 14 \\ \text { Guo et al 2020 } & 9 & 11 \\ \text { Härter et al 2020 } & 30 & 33 \\ \text { Hu et al 2020 } & 11 & 12 \\ \text { Huang et al 2020 } & 33 & 35 \\ \text { Liu et al 2020 } & 19 & 20 \\ \text { Meyerowitz et al 2020 } & 30 & 36 \\ \text { Nagarakanti et al 2021 } & 20 & 23 \\ \text { Sasset et al 2020 } & 1 & 2 \\ \text { SeyedAlinaghi et al 2020 } & 1 & 1 \\ \text { Sigel et al 2020 } & 70 & 88 \\ \text { Stoeckle et al 2020 } & 28 & 30 \\ \text { Swaminathan et al 2021 } & 4 & 6 \\ \text { Tian et al 2021 } & 1 & 1 \\ \text { Vizcarra et al 2020 } & 44 & 51 \\ \text { Yang et al 2021 } & 3 & 3 \\ & & \\ \text { Random effects model } & & 730 \\ \text { Heterogeneity: } I^{2}=27 \%, \tau^{2}=0.1335, p=0.12\end{array}$

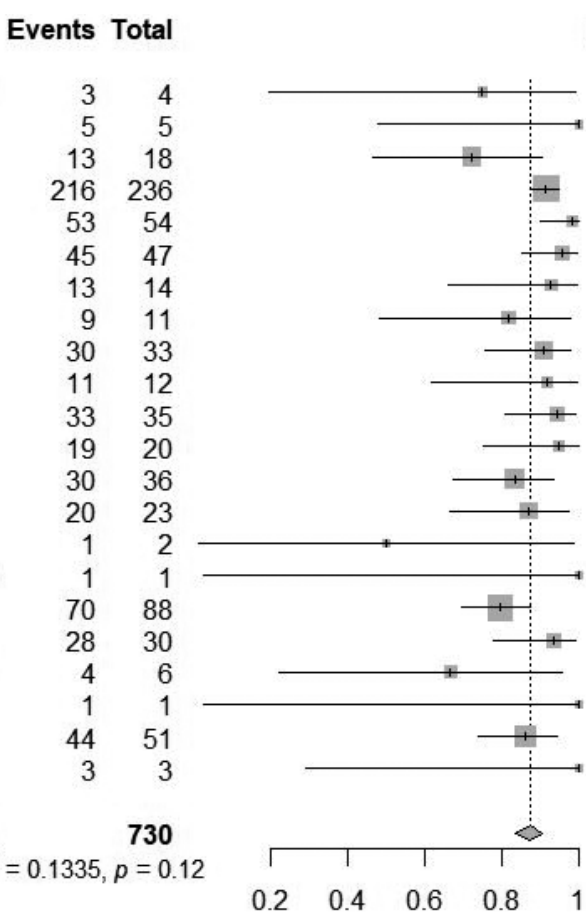

Proportion $\quad 95 \% \mathrm{Cl}$ Weight

$\begin{array}{rrr}0.75 & {[0.19 ; 0.99]} & 1.9 \% \\ 1.00 & {[0.48 ; 1.00]} & 1.2 \% \\ 0.72 & {[0.47 ; 0.90]} & 6.8 \% \\ 0.92 & {[0.87 ; 0.95]} & 14.8 \% \\ 0.98 & {[0.90 ; 1.00]} & 2.4 \% \\ 0.96 & {[0.85 ; 0.99]} & 4.2 \% \\ 0.93 & {[0.66 ; 1.00]} & 2.3 \% \\ 0.82 & {[0.48 ; 0.98]} & 3.7 \% \\ 0.91 & {[0.76 ; 0.98]} & 5.6 \% \\ 0.92 & {[0.62 ; 1.00]} & 2.3 \% \\ 0.94 & {[0.81 ; 0.99]} & 4.2 \% \\ 0.95 & {[0.75 ; 1.00]} & 2.3 \% \\ 0.83 & {[0.67 ; 0.94]} & 8.3 \% \\ 0.87 & {[0.66 ; 0.97]} & 5.4 \% \\ 0.50 & {[0.01 ; 0.99]} & 1.3 \% \\ 1.00 & {[0.03 ; 1.00]} & 1.0 \% \\ 0.80 & {[0.70 ; 0.87]} & 13.7 \% \\ 0.93 & {[0.78 ; 0.99]} & 4.1 \% \\ 0.67 & {[0.22 ; 0.96]} & 3.1 \% \\ 1.00 & {[0.03 ; 1.00]} & 1.0 \% \\ 0.86 & {[0.74 ; 0.94]} & 9.3 \% \\ 1.00 & {[0.29 ; 1.00]} & 1.1 \%\end{array}$

$0.87[0.83 ; 0.91] 100.0 \%$

Figure 4. Forest plot for the recovery proportion of coronavirus disease 2019/human immunodeficiency virus-coinfected patients amongst the included studies. $\mathrm{Cl}$, confidence interval.

ed mean of the estimates from each included study revealed differences in sample sizes between studies. However, using a random-effects model, the results showed an insignificant degree of heterogeneity between studies, as confirmed by the p-value $\left(\mathrm{I}^{2}=\right.$ $\left.27 \%, \mathrm{p}=0.12, \pi^{2}=0.1335\right)$. Although low, a considerable amount of the variability between studies $\left(\mathrm{I}^{2}=27 \%\right)$ could be attributed to clinical and methodological differences; for example, some studies included patients with multiple morbidities and those of older age, both of which are risk factors for a severe course of COVID-19, resulting in a lower recovery ratio. Furthermore, this systematic literature review included various observational study designs that may have contributed to a relatively high degree of variability.

\section{Publication bias}

The funnel plot showed a symmetrical scattering of points throughout the funnel, indicating that publication bias was unlikely. Furthermore, the Egger regression test revealed no significance in the asymmetry degree of the funnel plot $(\mathrm{p}=0.85)$ (Supplementary Material 3).

\section{DISCUSSION}

By December 2020, more than 73 million confirmed cases of COVID-19 and more than 1.6 million worldwide deaths had been reported by the WHO [2]. In line with the aim of this study, 730 patients coinfected with COVID-19 and HIV were investigated.
The majority of patients were male and most of them received antiretroviral drugs. Furthermore, $81.9 \%$ of coinfected cases had mild to moderate clinical symptoms, primarily including cough, fever, and dyspnoea $[20,35]$. Due to the impaired immune defences due to the underlying disease, including in patients receiving treatment, HIV patients were thought to be at higher risk of developing severe forms of COVID-19 [40]. Although comparative tests were not possible due to the limited data and differences in comparative groups between studies, some of the included studies revealed a similar representation of people living with HIV across the population. An earlier cohort from New York City, United States found no differences in adverse outcomes between HIV/ COVID-19-coinfected patients and a similar comparison group [34]. In Wuhan, China, a cohort study indicated that case-severity rates of COVID-19 in HIV patients were comparable to those in the overall population [28], and in Italy, coinfected HIV patients with COVID-19 were found to be at no higher risk of severe illness than HIV-negative patients [24].

While further research is needed to provide evidence regarding the prognosis of COVID-19 in HIV patients and other groups, this study has shown that older age and the presence of comorbidities, including hypertension, obesity, diabetes mellitus, renal diseases, cardiovascular diseases, chronic respiratory disease, liver disease, and malignancy, are associated with a poor prognosis in COVID-19 patients, including the risk of death. This aligns with an earlier report finding that the most prevalent comorbidities among COVID-19 patients were hypertension, obesity, chronic 
lung disease, and diabetes mellitus [41]. Further evidence on the relationship between pre-existing comorbidities and adverse outcomes of COVID-19 was reported in a previous systematic review, which found that older age and the presence of one or more comorbidities increased COVID-19 severity [42], and these findings also align with those presented by Meyerowitz et al. [30] who reported that $83 \%$ of all HIV/COVID-19-coinfected patients had comorbidities associated with severe COVID-19 outcomes. Considering the age factor, a relatively large cohort study found that older patients (median age, 63 years) had a higher risk of developing severe disease [43]. Despite the lower median age in this systematic literature review (51.5 years), some of the included studies confirmed a similar association in coinfected patients with COVID-19 and HIV [23,29], taking into account that the median age difference may be due to the changing age distribution of COVID-19 between May 2020 and August 2020, which is thought to be due to behavioural and occupational factors as younger people are less likely to follow safety precautions [44]. A similar age shift was identified in Europe, where the median age of COVID-19 cases was 54 years in the first half of 2020 and then decreased to 39 years during June-July 2020 [45].

As of December 31, 2020, almost 68 million (97\%) people had recovered from COVID-19 infection worldwide [2]. Despite the high recovery percentage globally, this systematic literature review showed a lower percentage of recovery in both a simple pooling of unweighted studies (90.6\% recovery) and a meta-analysis of proportions following weighting of studies (87.0\% recovery). These findings are consistent with the high proportion of death amongst HIV/COVID-19-coinfected patients (9.4\%). However, different studies have shown conflicting findings regarding the coinfectionrelated deaths in patients with HIV and COVID-19. Huang et al. [28] reported a lower percentage of death related to coinfection (5.71\%). A study in France [23], in contrast, reported a considerably lower percentage of deaths (1.8\%). This significant variation of results is most likely due to selection bias, as many patients were admitted to hospital with severe symptoms. Another reason may be the presence of confounders, including certain comorbidities or determinants that increase the risk of death from COVID-19, such as hypertension, obesity, diabetes mellitus, and old age [42], which is consistent with the findings of the included studies in this systematic literature review $[19,23,25,26,34,36]$.

Owing to the increase in the number of COVID-19 cases worldwide and the global demand for treatment, some HIV antiviral drugs have been under the spotlight. This particular interest was driven by a finding from the 2004 severe acute respiratory syndrome (SARS) outbreak, where it was observed that none of 19 HIV/AIDS patients receiving ART had contracted SARS despite being in close contact with SARS patients [46], which led to the hypothesis that the use of ART could prevent SARS from developing and could potentially reduce the severity and mortality of COVID-19. While the previous literature did not provide conclusive evidence on the effect of ART against SARS-CoV-2 infection [47], Elfiky [9] found that various antiviral drugs, including riba- virin, remdesivir, sofosbuvir, galidesivir, and tenofovir (NRTI) showed potential activity against SARS-CoV-2 by binding to its RdRp. This finding is congruous with previous studies suggesting that NRTIs inhibit the RdRp of COVID-19 and therefore may be effective against COVID-19 infection [48,49]. While this systematic literature review found that NRTIs were the most commonly used type of ART amongst HIV/COVID-19 patients, this finding cannot explain the relatively low severity of COVID-19 amongst HIV patients. Future research is therefore needed to further understand the role of antiretroviral drugs in reducing the severity of COVID-19 amongst HIV patients.

\section{Strengths and limitations}

In view of the rapidly changing evidence of the ongoing global pandemic, this study has been continuously updated over the course of 2020 and therefore includes relevant data. This research addresses an important and interesting concern that adds to the essential information needed to further understand the impact of COVID-19 on HIV patients. Considering the unstable and mutable nature of COVID-19, this study provides an up-to-date and in-depth analysis of the clinical outcomes of COVID-19 amongst HIV patients. Furthermore, the results highlight additional evidence on the clinical determinants of COVID-19 severity in HIV patients and their impact on patients' outcomes and quality of life. There are also some limitations to this study. First, most of the included studies have coinfected patients with a CD4 cell count greater than 200 cells $/ \mathrm{mm}^{3}$ and an HIV viral load lower than 50 copies/mL; thus, the results may not represent uncontrolled HIV patients. Second, while data on the antiretroviral drugs used in coinfected patients with HIV/COVID-19 were available, a comparison between the antiretroviral drugs received in coinfected cases of HIV/COVID-19 and HIV without COVID-19 was not possible due to lack of information. Some of the included studies lacked a comparison group and therefore provided limited information on the determinants associated with HIV/COVID-19 coinfection. For some of the results, the findings were influenced by a single large study [22]. Furthermore, most of the included studies had small samples, and various confounders were not included in the reporting of such data.

\section{CONCLUSION}

Based on the findings of this systematic literature review, coinfected patients with HIV/COVID-19 have marginally comparable clinical outcomes with the general population. HIV patients with pre-existing comorbidities should be considered as a high-risk COVID-19 group, along with those who are obese and older. Healthcare providers will therefore need to take particular care of HIV patients with multiple morbidities to prevent unnecessary poor outcomes. Given the mutable nature of COVID-19, HIV patients should still be advised to take additional precautions and protect themselves as new information is rapidly updated. Despite the lack of evidence on the effectiveness of antiretroviral drugs against 
COVID-19, controlled HIV patients with an undetectable HIV viral load appear to have better outcomes than uncontrolled patients. HIV patients should therefore be encouraged to adhere to their therapy. These findings highlight the need for further investigation of the impact of COVID-19 infection on HIV patients.

\section{SUPPLEMENTARY MATERIALS}

Supplementary materials are available at http://www.e-epih. org/.

\section{CONFLICT OF INTEREST}

The author has no conflicts of interest to declare for this study.

\section{FUNDING}

None.

\section{ACKNOWLEDGEMENTS}

None.

\section{AUTHOR CONTRIBUTIONS}

All work was done by TM.

\section{ORCID}

Thomas Massarvva: https://orcid.org/0000-0003-2243-155X

\section{REFERENCES}

1. European Centre for Disease Prevention and Control (ECDC). Timeline of ECDC's response to COVID-19 [cited 2020 Dec 21]. Available from: https://www.ecdc.europa.eu/en/covid-19/timeline-ecdc-response.

2. World Health Organization. WHO coronavirus (COVID-19) dashboard [cited 2020 Dec 21]. Available from: https://covid19. who.int/.

3. World Health Organization. Modes of transmission of virus causing COVID-19: implications for IPC precaution recommendations: scientific brief; 2020 Mar 29 [cited 2020 Dec 21]. Available from: https://www.who.int/news-room/commentaries/detail/ modes-of-transmission-of-virus-causing-covid-19-implicationsfor-ipc-precaution-recommendations.

4. Cooper TJ, Woodward BL, Alom S, Harky A. Coronavirus disease 2019 (COVID-19) outcomes in HIV/AIDS patients: a systematic review. HIV Med 2020;21:567-577.

5. Williamson EJ, Walker AJ, Bhaskaran K, Bacon S, Bates C, Morton CE, et al. Factors associated with COVID-19-related death using OpenSAFELY. Nature 2020;584:430-436.

6. Woodward WC. Can you explain AIDS and how it affects the immune system? How does HIV become AIDS?; 1999 [cited 2020 Nov 28]. Available from: https://www.scientificamerican. com/article/can-you-explain-aids-and/.

7. Liu A. Gilead halts emergency access to COVID-19 contender remdesivir amid 'overwhelming demand'; 2020 Mar 23 [cited 2020 Dec 18]. Available from: https://www.fiercepharma.com/ pharma/gilead-halts-emergency-access-to-covid-19-contenderremdesivir-amid-overwhelming-demand.

8. Zuniga JM. COVID-19 and HIV [cited 2020 Dec 18]. Available from: https://www.iapac.org/hiv-covid-19/.

9. Elfiky AA. Ribavirin, Remdesivir, Sofosbuvir, Galidesivir, and Tenofovir against SARS-CoV-2 RNA dependent RNA polymerase (RdRp): a molecular docking study. Life Sci 2020;253:117592.

10. Guo W, Ming F, Dong Y, Zhang Q, Liu L, Gao M, et al. Driving force of Covid-19 among people living with HIV/AIDS in Wuhan, China. Res Sq 2020. doi: doi: https://doi.org/10.21203/rs.3. rs-53351/v1.

11. Guan WJ, Ni ZY, Hu Y, Liang WH, Ou CQ, He JX, et al. Clinical characteristics of coronavirus disease 2019 in China. N Engl J Med 2020;382:1708-1720.

12. Centers for Disease Control and Prevention. What to know about HIV and COVID-19; 2020 [cited 2020 Dec 31]. Available from: https://www.cdc.gov/coronavirus/2019-ncov/need-extra-precautions/hiv.html.

13. Moher D, Liberati A, Tetzlaff J, Altman DG; PRISMA Group. Preferred reporting items for systematic reviews and meta-analyses: the PRISMA statement. PLoS Med 2009;6:e1000097.

14. van Tulder M, Furlan A, Bombardier C, Bouter L; Editorial Board of the Cochrane Collaboration Back Review Group. Updated method guidelines for systematic reviews in the Cochrane collaboration back review group. Spine (Phila Pa 1976) 2003;28:12901299.

15. Deeks JJ, Dinnes J, D’Amico R, Sowden AJ, Sakarovitch C, Song F, et al. Evaluating non-randomised intervention studies. Health Technol Assess 2003;7:iii-x, 1-173.

16. Viechtbauer W. Conducting meta-analyses in $\mathrm{R}$ with the metafor package. J Stat Softw 2010;36:1-48.

17. Jackson D. Confidence intervals for the between-study variance in random effects meta-analysis using generalised Cochran heterogeneity statistics. Res Synth Methods 2013;4:220-229.

18. Egger M, Davey Smith G, Schneider M, Minder C. Bias in metaanalysis detected by a simple, graphical test. BMJ 1997;315:629634.

19. Altuntas Aydin O, Kumbasar Karaosmanoglu H, Kart Yasar K. HIV/SARS-CoV-2 coinfected patients in Istanbul, Turkey. J Med Virol 2020;92:2288-2290.

20. Blanco JL, Ambrosioni J, Garcia F, Martínez E, Soriano A, Mallolas J, et al. COVID-19 in patients with HIV: clinical case series. Lancet HIV 2020;7:e314-e316.

21. Childs K, Post FA, Norcross C, Ottaway Z, Hamlyn E, Quinn K, et al. Hospitalized patients with COVID-19 and human immunodeficiency virus: a case series. Clin Infect Dis 2020;71:20212022. 
22. Del Amo J, Polo R, Moreno S, Díaz A, Martínez E, Arribas JR, et al. Incidence and severity of COVID-19 in HIV-positive persons receiving antiretroviral therapy: a cohort study. Ann Intern Med 2020;173:536-541.

23. Etienne N, Karmochkine M, Slama L, Pavie J, Batisse D, Usubillaga $\mathrm{R}$, et al. HIV infection and COVID-19: risk factors for severe disease. AIDS 2020;34:1771-1774.

24. Gervasoni C, Meraviglia P, Riva A, Giacomelli A, Oreni L, Minisci $\mathrm{D}$, et al. Clinical features and outcomes of patients with human immunodeficiency virus with COVID-19. Clin Infect Dis 2020; 71:2276-2278.

25. Gudipati S, Brar I, Murray S, McKinnon JE, Yared N, Markowitz N. Descriptive analysis of patients living with HIV affected by COVID-19. J Acquir Immune Defic Syndr 2020;85:123-126.

26. Härter G, Spinner CD, Roider J, Bickel M, Krznaric I, Grunwald S, et al. COVID-19 in people living with human immunodeficiency virus: a case series of 33 patients. Infection 2020;48:681-686.

27. $\mathrm{Hu} \mathrm{Y}, \mathrm{Ma}$ J, Huang $\mathrm{H}$, Vermund SH. Coinfection with HIV and SARS-CoV-2 in Wuhan, China: a 12-person case series. J Acquir Immune Defic Syndr 2020;85:1-5.

28. Huang J, Xie N, Hu X, Yan H, Ding J, Liu P, et al. Epidemiological, virological and serological features of COVID-19 cases in people living with HIV in Wuhan City: a population-based cohort study. Clin Infect Dis 2020:ciaa1186.

29. Liu J, Zeng W, Cao Y, Cui Y, Li Y, Yao S, et al. Effect of a previous history of antiretroviral treatment on clinical picture of patients with co-infection of SARS-CoV-2 and HIV: a preliminary study. Int J Infect Dis 2020;100:141-148.

30. Meyerowitz EA, Kim AY, Ard KL, Basgoz N, Chu JT, Hurtado RM, et al. Disproportionate burden of coronavirus disease 2019 among racial minorities and those in congregate settings among a large cohort of people with HIV. AIDS 2020;34:1781-1787.

31. Nagarakanti SR, Okoh AK, Grinberg S, Bishburg E. Clinical outcomes of patients with COVID-19 and HIV coinfection. J Med Virol 2021;93:1687-1693.

32. Sasset L, Di Meco E, Cavinato S, Cattelan AM. Coinfection of severe acute respiratory syndrome coronavirus 2 and HIV in a teaching hospital: still much to learn. AIDS 2020;34:1694-1696.

33. SeyedAlinaghi S, Ghadimi M, Hajiabdolbaghi M, Rasoolinejad M, Abbasian L, Nezhad MH, et al. Prevalence of COVID-19-like symptoms among people living with HIV, and using antiretroviral therapy for prevention and treatment. Curr HIV Res 2020;18: 373-380.

34. Sigel K, Swartz T, Golden E, Paranjpe I, Somani S, Richter F, et al. Coronavirus 2019 and people living with human immunodeficiency virus: outcomes for hospitalized patients in New York City. Clin Infect Dis 2020;71:2933-2938.

35. Stoeckle K, Johnston CD, Jannat-Khah DP, Williams SC, Ellman TM, Vogler MA, et al. COVID-19 in hospitalized adults with HIV. Open Forum Infect Dis 2020;7:ofaa327.
36. Swaminathan N, Moussa P, Mody N, Lo KB, Patarroyo-Aponte G. COVID-19 in HIV-infected patients: a case series and literature review. J Med Virol 2021;93:2557-2563.

37. Tian C, Tang L, Wu J, Li W, Ming X, Zhou H, et al. An HIV-infected patient with coronavirus disease 2019 has a favourable prognosis: a case report. Ann Palliat Med 2021;10:5808-5812.

38. Vizcarra P, Pérez-Elías MJ, Quereda C, Moreno A, Vivancos MJ, Dronda F, et al. Description of COVID-19 in HIV-infected individuals: a single-centre, prospective cohort. Lancet HIV 2020;7: e554-e564.

39. Yang R, Gui X, Zhang Y, Xiong Y, Gao S, Ke H. Clinical characteristics of COVID-19 patients with HIV coinfection in Wuhan, China. Expert Rev Respir Med 2021;15:403-409.

40. Ballester-Arnal R, Gil-Llario MD. The virus that changed Spain: impact of COVID-19 on people with HIV. AIDS Behav 2020;24: 2253-2257.

41. Garg S, Kim L, Whitaker M, O’Halloran A, Cummings C, Holstein $\mathrm{R}$, et al. Hospitalization rates and characteristics of patients hospitalized with laboratory-confirmed coronavirus disease 2019 - COVID-NET, 14 states, March 1-30, 2020. MMWR Morb Mortal Wkly Rep 2020;69:458-464.

42. Barek MA, Aziz MA, Islam MS. Impact of age, sex, comorbidities and clinical symptoms on the severity of COVID-19 cases: a meta-analysis with 55 studies and 10014 cases. Heliyon 2020;6:e05684.

43. Richardson S, Hirsch JS, Narasimhan M, Crawford JM, McGinn T, Davidson KW, et al. Presenting characteristics, comorbidities, and outcomes among 5700 patients hospitalized with COVID-19 in the New York City area. JAMA 2020;323:2052-2059.

44. Boehmer TK, DeVies J, Caruso E, van Santen KL, Tang S, Black $\mathrm{CL}$, et al. Changing age distribution of the COVID-19 pandemic - United States, May-August 2020. MMWR Morb Mortal Wkly Rep 2020;69:1404-1409.

45. European Centre for Disease Prevention and Control. Coronavirus disease 2019 (COVID-19) in the EU/EEA and the UK - eleventh update: resurgence of cases; 2020 Aug 10 [cited 2020 Dec 29]. Available from: https://www.ecdc.europa.eu/sites/default/ files/documents/covid-19-rapid-risk-assessment-20200810.pdf.

46. Chen XP, Cao Y. Consideration of highly active antiretroviral therapy in the prevention and treatment of severe acute respiratory syndrome. Clin Infect Dis 2004;38:1030-1032.

47. Ford N, Vitoria M, Rangaraj A, Norris SL, Calmy A, Doherty M. Systematic review of the efficacy and safety of antiretroviral drugs against SARS, MERS or COVID-19: initial assessment. J Int AIDS Soc 2020;23:e25489.

48. Chien M, Anderson TK, Jockusch S, Tao C, Kumar S, Li X, et al. Nucleotide analogues as inhibitors of SARS-CoV-2 polymerase. bioRxiv 2020. doi: http://dx.doi.org/10.1101/2020.03.18.997585.

49. Ju J, Li X, Kumar S, Jockusch S, Chien M, Tao C, et al. Nucleotide analogues as inhibitors of SARS-CoV polymerase. Pharmacol Res Perspect 2020;8:e00674. 